\title{
IMPROVING SCIENCE PROCESS SKILLS OF ELEMENTARY SCHOOL STUDENTS BY USING PROBLEM BASED LEARNING APPROACH
}

\author{
Lifda Sari. $\mathrm{S}^{1}$, Yanti Fitria ${ }^{2}$ \\ ${ }^{1,2}$ Universitas Negeri Padang, Padang, Indonesia \\ ${ }^{1}$ lifda.sari1973@gmail.com, ${ }^{2}$ yantifitria@ymail.com
}

\begin{abstract}
This research was motivated by the fact that many elementary school students still had low process skills. The purpose of this research was to improve the process skills of elementary school students by using PBL. This research was a classroom action research using Mac Taggart design. This design consisted of planning, implementation, observation, and reflection. This research was conducted at SDN 39 Mata Air Padang involving 30 students. This research was carried out in 2 cycles. The data were collected through observation sheets in the form of checklist which had been adjusted to measure the process skills. The indicators of process skills included skills for asking questions, making observations, identifying and classifying the results of observations being done, ability to interpret, skills in using tools and materials, planning activities, skills in using concepts obtained under new conditions, and the ability to present research results. Then, the data were analyzed by using two techniques, namely classical learning analysis technique and individual analysis technique. The results revealed that there was an improvement in the process skills of elementary school students after the implementation of PBL model. It was found that the average score in cycle 1 was 66.67 and it increased to 83.33 in cycle 2. The implications of this research served as the basis for teachers in developing the process skills of elementary school students.
\end{abstract}

Keywords: process skills, science, $P B L$

\section{PENINGKATAN KETERAMPILAN PROSES IPA SISWA SEKOLAH DASAR MENGGUNAKAN PENDEKATAN PROBLEM BASED LEARNING}

\begin{abstract}
ABSTRAK
Penelitian ini dilatarbelakangi oleh rendahnya keterampilan proses siswa sekolah dasar.Tujuan penelitian ini adalah untuk meningkatkan keterampilan proses siswa sekolah dasar dengan menggunakan PBL. Penelitian ini merupakan penelitian tindakan kelas dengan menggunakan desain Mac Taggart yang terdiri dari perencanaan, pelaksanaan, pengamatan dan reflesi. Penelitian ini dilaksanakan di SDN 39 Mata Air Kota Padang dengan jumlah siswa sebanyak 30 orang. Penelitian ini dilaksanakan sebanyak 2 siklus. Teknik pengumpulan data menggunakan lembar observasi guru dan siswa yang berbentuk cheklis dan telah disesuaikan untuk mengukur keterampilan proses. Adapun indikator keterampilan proses yaitu keterampilan untuk bertanya, keterampilan dalam melakukan pengamatan, keterampilan dalam mengidentifikasi dan mengklasifikasikan hasil pengamatan yang telah dilakukan, kemampuan dalam menafsirkan, keterampilan dalam menggunakan alat dan bahan, keterampilan merencanakan kegiatan, keterampilan menggunakan konsep yang telah didapatkan pada kondisi yang baru, dan kemampuan menyajikan hasil penelitian. Teknik analisis data terdiri dari dua yaitu teknik analisis kentuntasan belajar klasikal dan teknik analisis individu. Hasil penelitian menyatakan bahwa adanya adanya peningkatan keterampilan proses siswa sekolah dasar dengan menggunakan model PBL dari hasil keterampilan proses siklus 1 mendapatkan skor 66.67 meningkat pada siklus 2 mendapatkan skor 83.33. Implikasi penelitian ini dapat dijadikan sebagai landasan guru dalam mengembangkan keterampilan proses siswa sekolah dasar.
\end{abstract}

Kata Kunci: keterampilan proses, IPA, PBL

\begin{tabular}{|c|c|c|}
\hline Submitted & Accepted & Published \\
\hline 17 Oktober 2020 & 18 Januari 2021 & 27 Januari 2021 \\
\hline
\end{tabular}

\begin{tabular}{|l|l|c|c|c|}
\hline Citation & $:$ & $\begin{array}{c}\text { Sari. S, L., \& Fitria, Y. (2020). Improving Science Process Skills of Elementary School Students by Using Problem Based } \\
\text { Learning Approach. Jurnal PAJAR (Pendidikan dan Pengajaran), 5(1), 172-181. DOI : } \\
\text { http://dx.doi.org/10.33578/pjr.v5i1.8247. }\end{array}$ \\
\hline
\end{tabular}

\section{PENDAHULUAN}

Sekolah dasar merupakan sebuah lembaga pendidikan formal awal yang berada di Indonesia, (Kenedi et al. 2019). Setiap warga negara yang berada di Indonesia wajib mengikuti proses pembelajaran di sekolah dasar. Sekolah dasar merupakan lembaga pendidikan yang memiliki tujuan dan tanggung jawab yang besar terhadap proses pendidikan warga negara, (Kenedi et al, 2019). Sekolah dasar menjadi sekolah wajib yang harus dilaksanakan oleh warga negara dikarenakan sekolah dasar memiliki tujuan dan peran yang penting dalam proses 
pendidikan. Sekolah dasar mampu menfasilitasi siswa untuk memperoleh berbagi ilmu pengetahuan dan keterampilan serta berbagai bentuk nilai yang bertujuan membantu siswa untuk dapat bertahan dalam proses kehidupan. Disekolah dasar, siswa akan dibentuk untuk dapat menjadi individu yang memiliki kecerdasan baik dari aspek pengetahuan, sikap bahkan keterampilan, (Hidayah, 2015). Proses pembentukan dari ketiga aspek tersebut dilaksanakan secara sistematis dan bertahap yang disessuaikan dan proses perkembangan siswa sekolah dasar, (Kiswanto, 2017). Siswa akan dibelajarkan ilmu pengetahuan dan keterampilan yang sesuai dengan tingkat usianya. Hal ini bertujuan agar ilmu pengetahuan dan keterampilan yang diajarkan dapat terserap secara maksimal sehingga dapat membantu siswa dalam proses kehidupan sehari-hari.

Kehidupan dari masa ke masa mengalami proses perkembangan. Pada masa sekarang perkembangan kehidupan menuju arah perkembangan era digitalisasi atau yang dikenal dengan era revolusi industri 4.0. Era revolusi industri 4.0 merupakan era berkembangnya sistem infomasi dan teknologi, (Eliyasni, Kenedi and Sayer, 2019). Perkembangan ini bertujuan untuk dapat mempermudah kegiatan manusia. Oleh sebab itu pada masa ini siswa tidak hanya saya dituntut untuk memiliki pengetahuan semata, namun juga dituntut untuk memiliki berbagai macam keterampilan, (Helsa et al, 2019). Hal ini dikarenakan pada masa yang akan datang siswa akan dihadapi dengan berbagai macam permasalahan yang lebih kompleks serta membutuhkan berbagai macam keterampilan untuk mengatasi hal tersebut, (Ahmad et al, 2019). Oleh sebab itu keterampilan-keterampilan tersebut harus dibelajarkan dan dilatih pada usia sekolah dasar sehingga pada masa yang akan datang siswa telah terlatih memiliki keterampilan-keterampilan tersebut. Salah satu keterampilan yang harus dikuasai oleh siswa adalah keterampilan proses.

Keterampilan proses merupakan keterampilan yang menuntut siswa untuk dapat aktif dan mandiri dalam proses pembelajaran dengan memaksimalkan segala bentuk pengetahuan dan kompetensi yang dimiliki baik secara fisik maupun secara mental, (Ergül et al, 2011). Artinya keterampilan proses merupakan keterampilan yang menuntut siswa untuk belajar dari setiap proses yang dilaksanakan. Keterampilan proses ini perlu dikembangkan dan dilatih untuk siswa sekolah dasar dikarenakan keterampilan proses mampu memberikan pengalaman secara langsung dalam menemukan ilmu pengetahuan sehingga siswa mudah memahami ilmu pengetahuan tersebut, (Aydinli et al, 2011). Keterampilan proses akan memfasilitasi proses pembelajaran sehingga siswa akan terbiasa dalam menemukan ilmu pengetahuan yang ingin dipelajari, (Aydogdu et al, 2014). Proses ini lah yang selaras dengan keterampilan yang dibutuhkan pada era revolusi industri 4.0. Keterampilan dimana siswa harus menemukan solusi dari permasalahan tersebut. Oleh sebab itu keterampilan proses ini perlu dikembangkan dan dilatih untuk siswa sekolah dasar.

Keterampilan proses ini dapat dilakukan pada setiap proses pembelajaran. Namun akan lebih bermakna jika dilaksanakan pada proses pembelajaran IPA. Pembelajaran IPA merupakan pembelajaran wajib yang dibelajarkan disekolah dasar, (Kenedi, 2017). Pembelajaran IPA merupakan pembelajaran yang berhubungan dengan kehidupan sehari-hari terutama yang berhubungan dengan fenomena-fenomena serta gejala-gejala alam, (Astimar et al, 2019). Sehingga akan lebih tepat untuk mengembangkan keterampilan proses siswa sekolah dasar.

Untuk mengetahui kemampuan keterampilan proses siswa sekolah dasar maka peneliti meakukan observasi di kelas III SDN 39 Mata Air Kota Padang. Obeservasi dilaksanakan pada saat guru membelajarkan IPA. Pada proses pembelajaran tersebut terlihat guru mendominasi proses pembelajaran. Guru aktif dalam memberikan materi pembelajaran secara ceramah. Pada saat guru membelajarakan materi bentuk dan jenis daun, guru hanya memberikan penjelasan secara lisan dan pada akhir kegiatan guru memberikan evaluasi. Proses pembelajaran yang dilaksanakan oleh guru berdampak kepada aktivitas siswa. Pada observasi tersebut terlihat 
bahwa siswa hanya duduk dan mendengar apa yang disajikan oleh guru tanpa adanya umpan balik yang dilakukan oleh guru.

Setelah melakukan observasi maka peneliti melakukan analisis terhadap proses pembelajaran yang dilaksanakan oleh guru. Berdasarkan analisis peneliti terlihat bahwa proses pembelajaran yang dilaksanakan oleh guru terlihat bahwa tidak ada upaya dalam mengembangkan keterampilan proses siswa. Hal ini terlihat bahwa siswa hanya duduk mendengarkan guru dalam menyajikan materi. Pada proses pembelajaran jenis daun guru tidak melakukan proses bertanya jawab kepada siswa. Selain itu guru juga tidak meminta siswa melakukan proses pengamatan padahal guru bisa mengajak siswa untuk melakukan pengamatan dan percobaan. Sehingga tidak munculnya keterampilan proses siswa sekolah dasar. Sehingga dapat disimpulkan bahwa proses pembelajaran yang dilaksanakan oleh guru tidak mampu mengembangkan keterampilan proses siswa yang berakibatkan kepada rendahnya keterampilan proses siswa. Oleh sebab itu perlunya upaya untuk mengatasi permasalahan tersebut.

Berdasarkan diskusi peneliti dengan guru serta kajian literatur yang dilakukan maka salah satu upaya yang dapat dilakukan dalam meningkatkan keterampilan proses adalah dengan menerapan model problem based learning. Model problem based learning (PBL) merupakan sebuah model pembelajaran yang memfasilitasi siswa untuk mengembangkan serta melatih kemampuan yang mereka miliki dalam proses memecahkan permasalahan yang berhubungan dengan proses kehidupan sehari-hari, (Kenedi et al, 2019). Proses pemecahan masalah ini lah yang akan mampu memfasilitasi siswa untuk mengembangkan keterampilan proses siswa. Maka peneliti dan guru sepakat untuk mengatasi permasalahan tersebut dengan melakukan sebuah penelitian tindakan kelas. Maka tujuan dari penelitian ini adalah untuk mengetahui keterampilan proses siswa sekolah dasar pada pembelajaran IPA dengan menggunakan model pembelajaran Problem Based Learning.

\section{METODE PENELITIAN}

Penelitian ini merupakan penelitian tindakan kelas. Penelitian tindakan kelas merupakan penelitian yang bertujuan untuk mengatasi permasalahan yang dihadapi oleh guru dalam proses pembelajaran didalam kelas. Hal ini sesuai dengan tujuan penelitian ini adalah untuk meningkatkan kemampuan keterampilan proses siswa sekolah dasar yang masih rendah. Desain penelitian tindakan kelas ini menggunakan desain Mac Taggart yang terdiri dari perencanaan, pelaksanaan, pengamatan dan refleksi. Pada tahap perencanaan peneliti bersama menyusun segala hal yang akan dilaksanakan dalam proses penelitian. Pada tahap pelaksanaan peneliti melaksanakan penelitian yang didasari oleh perencanaan yang telah dirancang. Tahapan pengamatan, peneliti melakukan perngamatan terhadap proses pembelajaran yang meliputi aktivitas guru dan aktivitas siswa. Tahapan refleksi, peneliti melakukan peninjauan terhadap proses pembelajaran yang telah dilaksanakan.

Penelitian ini dilaksanakan di SDN 39 Mata Air Kota Padang dengan jumlah siswa sebanyak 30 orang. Penelitian ini dilaksanakan sebanyak 2 siklus. Teknik pengumpulan data menggunakan lembar observasi guru dan siswa yang berbentuk cheklis dan telah disesuaikan untuk mengukur keterampilan proses. Adapun indikator keterampilan proses yaitu keterampilan untuk bertanya, keterampilan dalam melakukan pengamatan, keterampilan dalam mengidentifikasi dan mengklasifikasikan hasil pengamatan yang telah dilakukan, kemampuan dalam menafsirkan, keterampilan dalam menggunakan alat dan bahan, keterampilan merencanakan kegiatan, keterampilan menggunakan konsep yang telah didapatkan pada kondisi yang baru, dan kemampuan menyajikan hasil penelitian.

Teknik analisis data terdiri dari dua yaitu teknik analisis kentuntasan belajar klasikal dan teknik analisis individu. adapun rumusnya sebagai berikut:

1. Analisis ketuntasan belajar klasikal Keterangan

$$
N P=\frac{R}{S N} X 100
$$


$\mathrm{NP}=$ Nilai persentase

$\mathrm{R}=$ Jumlah siswa yang memperoleh nilai $\geq 76$

$\mathrm{SN}=$ Jumlah seluruh siswa

2. Analisis aktivitas individu

Keterangan

$$
P a=\frac{A}{N} X 100
$$

$\mathrm{Pa}=$ Nilai persentase keterampilan proses

A = Jumlah nilai tercapai

$\mathrm{N}=$ Jumlah nilai penuh

Untuk mempermudah kategori keterampilan proses siswa maka dipedomani melalui tabel berikut:

Tabel 1. Kriteria Keterampilan Proses Siswa

\begin{tabular}{ll}
\hline Persentase Keterampilan Proses & Kriteria \\
\hline $86 \% \leq \mathrm{Pa} \leq 100 \%$ & Sangat Tinggi \\
\hline $68 \% \leq \mathrm{Pa} \leq 85 \%$ & Tinggi \\
\hline $51 \% \leq \mathrm{Pa} \leq 67 \%$ & Rendah \\
\hline $\mathrm{Pa}<50 \%$ & Sangat Rendah \\
\hline
\end{tabular}

Penelitian ini dikatakan berhasil apabila:

1. Nilai rata-rata keterampilan proses kelas memperoleh nilai $\geq 76$

2. Adanya peningkatan aktivitas guru dengan nilai akhir memperoleh nilai $\geq 76$

3. Adanya peningkatan keterampilan proses siswa

\section{HASIL DAN PEMBAHASAN}

Kegiatan pertama yang dilakukan dalam penelitian ini adalah dengan melakukan tahapan perencanaan yang terdiri dari menyusun rencanan pelaksanaan pembelajaran (RPP). Penyusunan RPP ini bertujuan agar menjadi pedoman guru dalam melaksanakan kegiatan perbaikan. RPP ini didesaian dengan mengikuti langkan PBL dengan materi mengenal sifat benda (padat). Selain itu guru dan peneliti juga mempersiapkan media pembelajaran dan alat, bahan, LKPD yang digunakan dalam proses percobaan. Selain itu guru dan peneliti juga menyusun pedoman observasi aspek guru dalam melaksanakan proses pembelajaran PBL dan pedoman observasi aspek siswa yang digunakan dalam mengukur keterampilan proses siswa sekolah dasar. Setelah menyusun perencanaan maka selanjutnya dilaksanakan proses pelaksannaan penelitian.

Pelaksanaan pembelajaran didasari oleh RPP yang telah dikembangkan. Pada kegiatan awal guru mempersiapakan proses pembelajaran seperti berdoa, absensi, dan membuka skemata siswa mengenai benda-benda yang berada disekitar melalui proses tanya jawab. Pada awal kegiatan inti guru memberikan orientasi kepada siswa. Guru menyampaikan tujuan pembelajaran yaitu mengindentifikasi ciri-ciri benda padat yang telah didiskusikan pada awal kegiatan tadi. Guru mengajukan beberapa contoh benda-benda padat dan meminta siswa memberikan respon terhadap benda padat yang disajikan. Kemudian guru mengorganisasikan siswa dengan membagi siswa kedalam beberapa kelompok. Guru meminta siswa untuk melakukan percobaan yang ada didalam LKPD.

Selama proses percobaaan kelompok guru membimbing siswa dan membantu siswa yang mengalami kendala. Selama pelaksanaan percobaan siswa diberikan kebebasan untuk memecahkan permasalahan dengan berbagai macam cara. Terlihat pada proses pelaksanaan percobaan ada beberapa kelompok yang mengalami kendala dan tidak fokus terhadap percobaan yang dilakukan. Seanjutnya guru meminta siswa untuk mempresentasikan temuanya. Terlihat hanya beberapa siswa yang semangat dalam melakukan presentasi kegiatan. Pada akhir kegiatan guru melakukab refleksi terhadap percobaaan yang dilakukan dan memberikan penguatan terhadap hasil yang ditemukan.

Selam proses pelaksanaan juga dilakukan proses pengamatan. Pengamatan dilakukan oleh 
teman sejawat yang bertugas mengamati proses pelaksanaan pembelajaran oleh guru dan keterampilan proses siswa. Adapun hasil pengamatan aktivitas guru dapat dilihat pada tabel berikut:

Tabel 2. Skor Aktivitas Guru

\begin{tabular}{ll}
\hline Aktivitas Guru & Skor \\
\hline Orientasi siswa pada masalah & 15 \\
\hline Mengorganisasi siswa & 10 \\
\hline $\begin{array}{l}\text { Membimbing penyelidikan } \\
\text { individu maupun kelompok }\end{array}$ & 10 \\
\hline Mengembangkan dan menyajikan hasil & 15 \\
\hline $\begin{array}{l}\text { Menganalisis dan mengevaluasi proses dan } \\
\text { hasil pemecahan masalah }\end{array}$ & 10 \\
\hline Jumlah & 60 \\
\hline
\end{tabular}

Dari tabel 2 tersebut terlihat skor akhir aktivitas guru mendapatkan skor 60. Hal ini membuktikan bahwa belum tercapainya indikator keberhasilan yang telah ditetetapkan. Selain mengamati aktivitas guru, observer juga mengamati keterampilan proses siwa. Adapun hasil rata keterampilan proses siswa dapat dilihat pada tabel berikut:

Tabel 3. Skor Keterampilan Proses Siswa

\begin{tabular}{lc}
\hline Aktivitas Guru & Skor \\
\hline Kemampuan bertanya & 66.67 \\
\hline Kemampuan melakukan pengamatan & 66.67 \\
\hline Kemampuan mengidentifikasi dan mengklasifikasi hasil pengamatan & 66.67 \\
\hline Kemampuan menafsirkan hasil identifikasi dan klasifikasi & 66.67 \\
\hline Kemampuan mengunakan alat dan bahan untuk memperoleh pengalaman secara langsung & 66.67 \\
\hline Kemampuan merencanakan suatu kegiatan penelitian & 66.67 \\
\hline Kemampuan mengunakan dan menerapkan konsep yang telah dikuasai dalam suatu situasi baru & 66.67 \\
\hline Kemampuan menyajikan suatu hasil pengamatan atau hasil penelitian & 66.67 \\
\hline Rata-rata & 66.67 \\
\hline Kategori & Rendah \\
\hline
\end{tabular}

Dari tabel 3 tersebut terlihat bahwa keterampilan proses siswa mendapatkan skor akhir 69.17 sehingga belum mencapai indikator keberhasilan Selain itu ketuntasan klasikal baru mencapai $73.33 \%$.

Tahapan selanjutnya adalah tahapan refleksi yang bertujuan untuk meninjau kembali proses kegiatan yang telah dilaksanakan. Dari hasil pengamatan aktivitas guru ditemukan bahwa skor akhir belum mencapai indikator kerberhasilan dengan kategori rendah. Hal ini juga didasari oleh catatan lapangan observasi yang menyatakan ada beberapa bagian kegiatan yang tidak dilaksanakan oleh guru seperti guru tidak terlalu membimbing siswa pada saat melakukan percobaan sehingga siswa banyak yang tidak mengerti apa yang harus dikerjakan. Selain itu pada proses percobaaan guru dan penyajian hasil guru tidak memberikan motivasi sehingga hanya beberapa anak saja yang aktif melakukan kegiatan. Hasil catatan ini lah yang akan diperbaharui pada siklus selanjutnya. Guru harus lebih memperhatikan dan membimbing siswa serta memotivasi siswa agar dapat melakukan penyelidikan dan persentasi hasil dengan baik. Berdasarkan hasil refleksi dikarenakan belum 
tercapainya indikator keberhasilan maka guru dan peneliti sepakat untuk melanjutkan penelitian pada siklus ke dua.

Kegiatan pertama yang dilakukan pada siklus kedua ini adalah dengan melakukan tahapan perencanaan yang terdiri dari menyusun RPP. RPP ini didesaian dengan mengikuti langkan PBL pada materi mengenal sifat benda (cair dan gas). Selain itu guru dan peneliti juga mempersiapkan media pembelajaran dan alat, bahan, LKPD yang digunakan dalam proses percobaan. Guru dan peneliti juga menyusun pedoman observasi aspek guru dalam melaksanakan proses pembelajaran PBL dan pedoman observasi aspek siswa yang digunakan dalam mengukur keterampilan proses siswa sekolah dasar. Setelah menyusun perencanaan maka selanjutnya dilaksanakan proses pelaksannaan penelitian.

Pelaksanaan pembelajaran didasari oleh RPP yang telah dikembangkan. Pada kegiatan awal guru mempersiapakan proses pembelajaran seperti berdoa, absensi, dan membuka skemata siswa mengenai benda-benda yang berada disekitar melalui proses tanya jawab. Pada awal kegiatan inti guru memberikan orientasi kepada siswa. Guru menyampaikan tujuan pembelajaran yaitu mengindentifikasi ciri-ciri benda gas dan cair. Guru mengajukan beberapa contoh bendabenda gas dan cair dan meminta siswa memberikan respon terhadap benda tersebut. Kemudian guru mengorganisasikan siswa dengan membagi siswa kedalam beberapa kelompok. Guru meminta siswa untuk melakukan percobaan yang ada didalam LKPD.

Selama proses percobaaan kelompok guru membimbing siswa dan membantu siswa yang mengalami kendala.. Guru memberikan bimbingan terhadap siswa maupun kelompok yang mengalami kendala serta memberikan motivasi kepada siswa. Sehingga dapat dilihat bahwa sisw aktif dalam melakukan setiap percobaan. Selanjutnya guru meminta siswa untuk mempresentasikan temuanya. Guru memotivasi siswa untuk terlibat aktif dalam proses peyajian hasil percobaan sehingga diskusi berjalan aktif. Pada akhir kegiatan guru melakukan refleksi terhadap percobaaan yang dilakukan dan memberikan penguatan terhadap hasil yang ditemukan.

Selama proses pelaksanaan juga dilakukan proses pengamatan. Adapun hasil pengamatan aktivitas guru dapat dilihat pada tabel berikut:

Tabel 4. Skor Aktivitas Guru

\begin{tabular}{ll}
\hline Aktivitas Guru & Skor \\
\hline Orientasi siswa pada masalah & 20 \\
\hline Mengorganisasi siswa & 15 \\
\hline $\begin{array}{l}\text { Membimbing penyelidikan } \\
\text { individu maupun kelompok }\end{array}$ & 15 \\
\hline Mengembangkan dan menyajikan hasil & 20 \\
\hline $\begin{array}{l}\text { Menganalisis dan mengevaluasi proses dan } \\
\text { hasil pemecahan masalah }\end{array}$ & 15 \\
\hline Jumlah & 80 \\
\hline
\end{tabular}

Dari tabel 4 tersebut terlihat skor akhir aktivitas guru mendapatkan skor 85. Hal ini membuktikan bahwa tercapainya indikator keberhasilan yang telah ditetetapkan. Selain mengamati aktivitas guru, observer juga mengamati keterampilan proses siwa. Adapun hasil rata keterampilan proses siswa dapat dilihat pada tabel berikut: 
Jurnal PAJAR (Pendidikan dan Pengajaran)

Volume 5 Nomor 1 Januari 2021 | ISSN Cetak : 2580 - 8435 | ISSN Online : 2614 - 1337

DOI : http://dx.doi.org/10.33578/pir.v5i1.8247

Tabel 5. Skor Keterampilan Proses Siswa

\begin{tabular}{lc}
\hline Aktivitas Guru & Skor \\
\hline Kemampuan bertanya & 76.67 \\
\hline Kemampuan melakukan pengamatan & 76.67 \\
\hline Kemampuan mengidentifikasi dan mengklasifikasi hasil pengamatan & 83.33 \\
\hline Kemampuan menafsirkan hasil identifikasi dan klasifikasi & 83.33 \\
\hline Kemampuan mengunakan alat dan bahan untuk memperoleh pengalaman secara langsung & 86.67 \\
\hline Kemampuan merencanakan suatu kegiatan penelitian & 86.67 \\
\hline Kemampuan mengunakan dan menerapkan konsep yang telah dikuasai dalam suatu situasi baru & 83.33 \\
\hline Kemampuan menyajikan suatu hasil pengamatan atau hasil penelitian & 86.67 \\
\hline Rata-rata & 83.33 \\
\hline
\end{tabular}

Dari tabel 5 tersebut terlihat bahwa keterampilan proses siswa mendapatkan skor akhir 83.33 sehingga telah mencapai indikator keberhasilan. Selain itu ketuntasan klasikal sudah mencapai $100 \%$.

Tahapan selanjutnya adalah tahapan refleksi yang bertujuan untuk meninjau kembali proses kegiatan yang telah dilaksanakan. Dari hasil pengamatan aktivitas guru ditemukan bahwa skor akhir belum telah indikator kerberhasilan dan begitu juga dengan hasil keterampilan proses siswa yang telah mencapai indikator keberhasilan. Sehingga dapat disimpulkan bahwa telah terjadinya peningkatan keterampilan proses siswa dengan menggunakan model PBL. Adapun grafik ringkasan peningkatan keterampilan proses siswa dapat dilihat pada gambar dibawah ini:

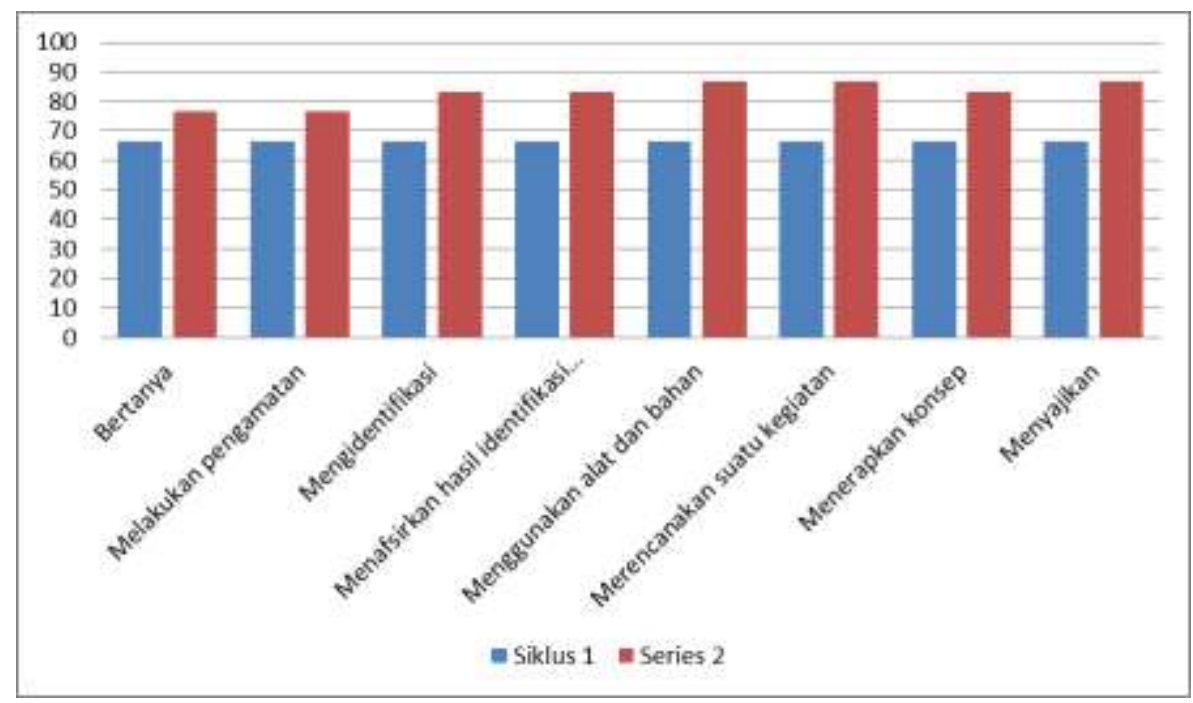

Gambar 1. Ringkasan Keterampilan Proses Siswa

Dari gambar 1 Tersebut dapat terlihat bahwa adanya peningkatan keterampilan proses siswa sekolah dasar dengan menggunakan model PBL.

Keterampilan proses merupakan keterampilan yang dimiliki siswa dari setiap proses yang dilalui, (Saputro et al, 2019). Keterampilan proses ini sangat penting dikembangkan untuk siswa sekolah dasar dikarenakan dengan menerapkan keterampilan proses siswa mampu memahami ilmu pengetahuan secara menyeluruh, (Durmaz and 
Mutlu, 2017). Penelitian tindakan kelas ini membuktikan bahwa model PBL mampu meningkatkan keterampilan proses siswa sekolah dasar. PBL merupakan sebuah model pembelajaran yang menjadikan permasalahan sebagai landasan dalam pembelajaran, (Bell, 2010). PBL menuntut siswa untuk aktif dalam memecahkan permasalahan yang disajikan. PBL dapat meningkatkan keterampilan proses siswa dikarenakan setiap langkan PBL memfasilitasi siswa untuk mengembangkan keterampilan prosesnya. Langkah PBL yang pertama yaitu orientasi siswa pada masalah dapat mengembangkan kemampuan bertanya dan kemampuan mengamati Pada orientasi siswa terhadap masalah, guru akan membuka skemata siswa melalui proses tanya jawab. Proses tanya jawab inilah yang akan melatih kemampuan siswa dalam bertanya. Selain itu pada tahapan ini guru juga akan meminta siswa untuk melakukan pengamatan terhadap benda-benda yang berhubungan dengan materi yang akan dibelajarkan. Hal ini selaras dengan pernyataan bahwa pada proses orientasi masalah dapat dilakukan melalui tanya jawab dan pengamatan, (Hung et al, 2014; Baysal, 2017). Pada tahap mengorganisasi, siswa akan mampu mengembangkan kemampuan mengidentifikasi dan mengklasifikasi serta menafsirkan hasil pengamatan. Hal ini senada dengan pendapat bahwa pada tahap organisasi siswa dapat melakukan identifikasi dan klasifikasi materi yang akan dipelajari, (Tsai et al, 2015; Kaharuddin et al, 2019).

Pada tahapan penyelidikan juga akan
mampu menggunakan alat, merencanakan, dan menggunakan konsep. Hal ini dikarenakan pada tahapan penyelidikan, siswa akan melakukan percobaan dengan menggunakan alat. Selain itu siswa juga akan merencanakan mekanisme apa saja yang akan dilakukan. Hal ini senada dengan pendapat bahwa pada tahapan penyelidikan siswa harus mampu merencanakan penyelidikan serta menggunakan alat dan bahan apa saja yang diperlukan, (Anugraheni, 2018; Nurlaily et al, 2019). Selain itu tahapan mengembangkan dan menyajikan hasil juga akan mampu melatih siswa untuk meningkatkan kemampuan menyajikan hasil pengamatan. Hal ini selaras dengan pendapat bahwa pada tahapan penyajian siswa harus mampu mengkomunikasikan hasil penyelidikan yang telah dilakukan, (Amelia, 2018). Hal-hal inilah yang menjadikan terjadinya peningkatan kemampuan keterampilan proses siswa sekolah dasar dengan menggunakan model PBL.

\section{SIMPULAN DAN REKOMENDASI}

Penelitian ini membuktikan adanya peningkatan keterampilan proses siswa sekolah dasar dengan menggunakan model PBL dari hasil keterampilan proses siklus 1 mendapatkan skor 66.67 meningkat pada siklus 2 mendapatkan skor 83.33. Rekomendasi untuk penelitian ini adalah agar guru dapat mempersiapkan permasalahan yang sesuai dengan tingkat perkembangan siswa. Penelitian ini juga merekomendasikan agar guru dapat memotivasi siswa dalam melaksanakan proses pembelajaran.

\section{DAFTAR PUSTAKA}

Ahmad, S. S., Ahmad, S., Kenedi, A. K., \& Helsa, Y. (2019, December). Learning Model and Higher-Order Thinking Skill in Advanced Mathematical Study. In 5th International Conference on Education and Technology (ICET 2019). Atlantis Press.

Amelia, R. (2018, December). The Application of Problem Based Learning (PBL) Approach for Elementary Schools Teachers. In 1st International Conference on Creativity, Innovation and Technology in Education (IC-CITE 2018). Atlantis Press.

Anugraheni, I. (2018). Meta Analisis Model Pembelajaran Problem Based Learning dalam Meningkatkan Keterampilan Berpikir Kritis di Sekolah Dasar [A Metaanalysis of Problem-Based Learning Models in Increasing Critical Thinking Skills in Elementary Schools]. Polyglot: Jurnal Ilmiah, 14(1), 9-18.

Astimar, N., Helsa, Y., \& Kenedi, A. K. (2019, December). The review of utilization in natural environment by the teacher as a source for learning science at elementary 
school in low class. In Journal of Physics: Conference Series (Vol. 1424, No. 1, p. 012036). IOP Publishing.

Aydinli, E., Dokme, I., Ünlüa, Z. K., Öztürk, N., Demir, R., \& Benli, E. (2011). Turkish elementary school students' performance on integrated science process skills. Procedia-Social and Behavioral Sciences, 15, 3469-3475.

Aydogdu, B., Erkol, M., \& Erten, N. (2014, June). The Investigation of Science Process Skills of Elementary School Teachers in Terms of Some Variables: Perspectives from Turkey. In Asia-Pacific Forum on Science Learning and Teaching (Vol. 15, No. 1, p. n1). Hong Kong Institute of Education. 10 Lo Ping Road, Tai Po, New Territories, Hong Kong.

Baysal, Z. N. (2017). The Problem-Based Learning Process: Reflections of PreService Elementary School Teachers. Educational Research and Reviews, 12(4), 177-188.

Bell, S. (2010). Project-based learning for the 21st century: Skills for the future. The clearing house, 83(2), 39-43.

Durmaz, H., \& Mutlu, S. (2017). The effect of an instructional intervention on elementary students' science process skills. The Journal of Educational Research, 110(4), 433-445.

Eliyasni, R., Kenedi, A. K., \& Sayer, I. M. (2019). Blended Learning and Project Based Learning: The Method to Improve Students' Higher Order Thinking Skill (HOTS). Jurnal Iqra': Kajian Ilmu Pendidikan, 4(2), 231-248.

Ergül, R., Şımşeklı, Y., Çaliş, S., Özdılek, Z., Göçmençeleb1, Ş., \& Şanli, M. (2011). The Effects Of Inquiry-Based Science Teaching On Elementary School Students'science Process Skills And Science Attitudes. Bulgarian Journal of Science \& Education Policy, 5(1), 48-68.

Helsa, Y. Y., Helsa, Y., Ariani, Y., \& Kenedi, A. K. (2019, December). Digital Class Model in Mathematics Learning in Elementary School Using Social Learning
Network Schoology. In 5th International Conference on Education and Technology (ICET 2019). Atlantis Press.

Hidayah, N. (2015). Pembelajaran Tematik Integratif di Sekolah Dasar. Terampil: Jurnal Pendidikan dan Pembelajaran Dasar, 2(1), 34-49.

Hung, P. H., Hwang, G. J., Lee, Y. H., Wu, T. H., Vogel, B., Milrad, M., \& Johansson, E. (2014). A problem-based ubiquitous learning approach to improving the questioning abilities of elementary school students. Journal of Educational Technology \& Society, 17(4), 316-334.

Kaharuddin, A. (2019). Effect of Problem Based Learning Model on Mathematical Learning Outcomes of 6th Grade Students of Elementary School Accredited B in Kendari City. International Journal of Trends in Mathematics Education Research, 1(2), 43-46.

Kenedi, A. K. (2017). Peningkatan Hasil Belajar Siswa Pada Pembelajaran Ipa Dengan Menerapkan Strategi Problem Based Learning (PBL) Di Sekolah Dasar. Jurnal Ilmiah Pendidikan Guru Sekolah Dasar, 1(1), 1-10.

Kenedi, A. K., Chandra, R., \& Fitria, Y. (2019, December). Problem based learning: a way to improve critical thinking ability of elementary school students on science learning. In Journal of Physics: Conference Series (Vol. 1424, No. 1, p. 012037). IOP Publishing.

Kenedi, A. K., Eliyasni, R., \& Fransyaigu, R. (2019, December). Jigsaw using animation media for elementary school. In Journal of Physics: Conference Series (Vol. 1424, No. 1, p. 012027). IOP Publishing.

Kenedi, A. K., Helsa, Y., Ariani, Y., Zainil, M., \& Hendri, S. (2019). Mathematical Connection of Elementary School Students to Solve Mathematical Problems. Journal on Mathematics Education, 10(1), 69-80.

Kiswanto, A. (2017, September). The Effect Of Learning Methods And The Ability Of 
Students Think Logically To The Learning Outcomes On Natural Sciences Of Grade IvS Student. In 9th International Conference for Science Educators and Teachers (ICSET 2017). Atlantis Press.

Nurlaily, V. A., Soegiyanto, H., \& Usodo, B. (2019). Elementary School Teachers' Obstacles in the Implementation of Problem-Based Learning Model in Mathematics Learning. Journal on Mathematics Education, 10(2), 229-238.

Saputro, A. D., Irwanto, I., Atun, S., \& Wilujeng, I. (2019). The impact of problem solving instruction on academic achievement and science process skills among prospective elementary teachers. Elementary Education Online, 18(2), 496-507.

Tsai, C. W., Shen, P. D., \& Lu, Y. J. (2015). The effects of Problem-Based Learning with flipped classroom on elementary students' computing skills: A case study of the production of Ebooks. International Journal of Information and Communication Technology Education (IJICTE), 11(2), 32-40. 